\title{
Geographic range extension to Wyoming, USA, for Paraleptophlebia praepedita (Eaton, 1884) (Insecta: Ephemeroptera: Leptophlebiidae)
}

\author{
Ashley Garlick ${ }^{1}$, Boris C. Kondratieff ${ }^{2}$ and Luke M. Jacobus ${ }^{1 *}$ \\ 1 Indiana University Purdue University Columbus (IUPUC), 4601 Central Ave., Columbus, Indiana, (IN), 47203, USA \\ 2 Colorado State University, Department of Bioagricultural Sciences and Pest Management, Fort Collins, Colorado, (CO), 80523, USA \\ * Corresponding author. E-mail: lukemjacobus@alumni.purdue.edu
}

\begin{abstract}
New distribution data from Carbon Co., Wyoming, extend the USA range of Paraleptophlebia praepedita (Eaton, 1884) westwards, with the nearest records being from eastern Iowa, Minnesota and Missouri. The new record is based on male adults collected from riparian vegetation. Paraleptophlebia praepedita is one of at least five predominantly eastern North American aquatic insect species with disjunct populations in the uranium mining areas of the western North Platte River drainage.
\end{abstract}

Eaton (1884: 99) described Paraleptophlebia praepedita (Eaton, 1884), (Ephemeroptera, Leptophlebiidae) based on the male adult stage from Dedham, Massachusetts; Spieth (1941) subsequently verified the type concept and designated a lectotype. Needham (1905: 50) provided the first larval description based on reared material from Illinois.

The male adult is distinguished from other North American congeners by the combination of having the middle abdominal segments predominantly brown; and by having each penes lobe elongate, nearly as long as the forceps, and with a terminal nipple and a rounded-tipped reflexed spur that curves slightly outward and upward (Traver 1935; Burks 1953). The larva is distinguished from others by the combination of having tuskless mandibles that are not enlarged, gills that are divided near their bases, the combined length of maxillary palp segments $2+3$ nearly subequal to segment 1 , legs without distinct banding, gills without prominent lateral setation, and abdominal sterna with dark brown lateral coloration that usually contrasts the medial coloration (Traver 1935). Zhou et al. (2009) provided DNA barcode data for molecular identification of this species.

Paraleptophlebia praepedita has a wide distribution in eastern North America, with incursions into central and western Canada (Figure 1). It has been reported from the Canadian provinces (McCafferty and Randolph 1998) of Alberta (Clifford and Boerger 1974), Manitoba (McDunnough 1925a; Gyselman 1980; Zhou et al. 2009, 2010; Webb et al. 2012), Nova Scotia (Jacobus and McCafferty 2001a), Ontario (Clemens 1915; McDunnough 1925a; Ide 1930; Mathers 1978), Quebec (McDunnough 1925a, c) and Saskatchewan (Lehmkuhl 1976), and from the USA states of Alabama (Harris et al. 1996; McCafferty et al. 2010), Arkansas (Cather and Harp 1975; McCafferty et al. 2010), Illinois, Indiana, Michigan, Ohio (Randolph and McCafferty 1998), Iowa (Klubertanz 1995; McCafferty et al. 2003), Massachusetts (Eaton 1884), Minnesota
(Lager et al. 1982), Missouri (Sarver and Kondratieff 1997), New York (Jacobus and McCafferty 2001b), West Virginia (Faulkner and Tarter 1977; McCafferty et al. 2010) and Wisconsin (McCafferty 2009). McCafferty et al. (2012: 242) inadvertently listed P. praepedita for Colorado. Therefore, this report should be disregarded, because they provided no substantiating data for this report and no species account for it in the Intermountain West region (McCafferty 2000).

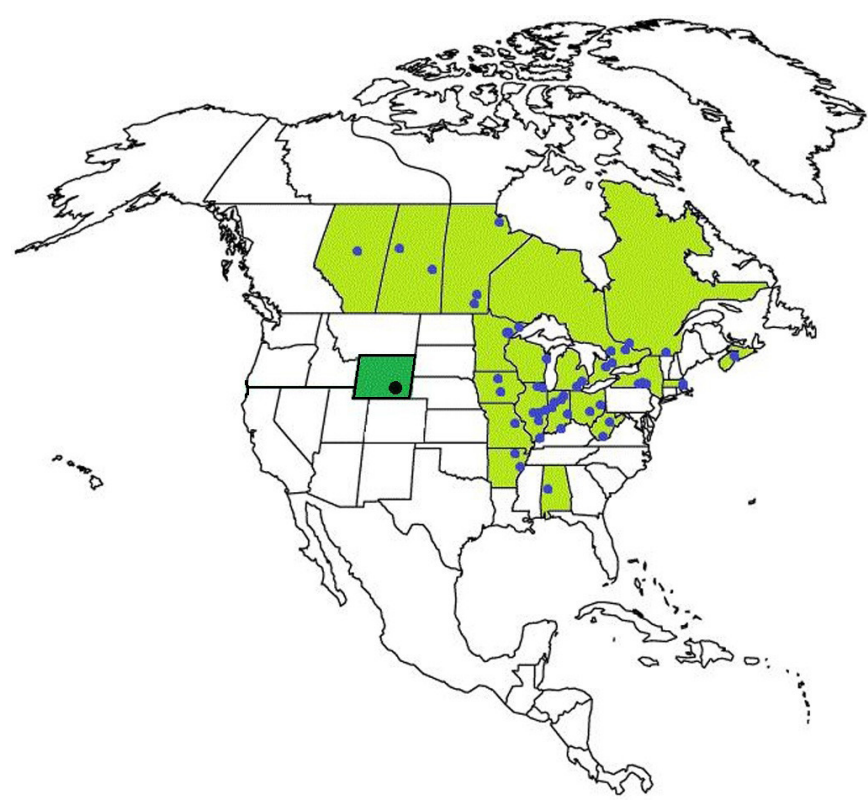

FiguRE 1. Distribution map for Paraleptophlebia praepedita. States and provinces home to previous records shaded with light green; Wyoming indicated with dark green. Previous record locales indicated with dark blue circles. New Wyoming record locale indicated by black circle.

Recently, $P$. praepedita was collected in eastern Wyoming. The specimens were found perching on streamside vegetation. They were placed in plastic bags and returned to the laboratory for fixation, preservation, labeling, identification and morphological scrutiny. The 
finding of this species in Wyoming marks a significant new distribution record of the taxon (Figure 1), extending its USA range west, with the nearest records from Iowa, Minnesota and Missouri (Lager et al. 1982; Klubertanz 1995; Sarver and Kondratieff 1997; McCafferty et al. 2003). New data are as follows: USA, Wyoming, Carbon County, Muddy Creek at State Route 487, 42¹2'39.06” N, $106^{\circ} 15^{\prime} 26.496^{\prime \prime}$ W, July 2010, T. Schmidt, two male adults, voucher numbers 12LJ01, 12LJ02 (deposited in the C. P. Gillette Museum of Arthropod Diversity, Colorado State University, Fort Collins, Colorado, USA).

Muddy Creek is a drainage unit of the Shirley Basin, an area typical of the eastern high Wyoming plains with moderate elevation changes. Elevation at the site of the collection was approximately 2,070 m. The climate is considered arid to semi-arid, with low annual precipitation and a frost-free growing season of 90 to 110 days. Temperatures are moderately warm during the summer and cold in the winter. Extreme fluctuations in temperatures from day to day and in annual precipitation from year to year are common (Knight 1996). The Shirley Basin is a southward extension of the Wind River Basin and lies between the Sweeter Arch and the Laramie Range. Stream substrate reflects the major bedrock units of the Wind River and White River shale formations (Knight 1996). This area is well known for uranium mining (Melin 1964).

Paraleptophlebia praepedita is a third mayfly species to demonstrate an atypical distribution pattern that includes much of central and eastern North America, with a disjunction in the North Platte Drainage in Colorado or Wyoming. Others include Heterocloeon frivolum (McDunnough, 1925b) (Baetidae) and Rhithrogena manifesta Eaton, 1885 (Heptageniidae). Durfee and Kondratieff (1994) indicated that other primarily aquatic insects follow this disjunct pattern, including, for example, Taeniopteryx parvula Banks, 1918 (Plecoptera: Taeniopterygidae), and Pycnopsyche guttifer (Walker, 1852) (Trichoptera: Limnephilidae) (Ruiter and Lavigne 1985; Kondratieff and Baumann 1988; Ruiter 1990). The Platte subsystem once may have acted as a conduit from more eastern regions of the Missouri River Drainage for these species (McCafferty et al. 2012).

Acknowledgments: Travis S. Schmidt (U.S. Geological Survey, Water Resources Division, Fort Collins Science Center, Fort Collins, Colorado) made specimens available for study. Pat Randolph (University of California, Davis, California) assisted with tracking published record data, and Jeff Webb (Rhithron Associates, Missoula, Montana, USA) provided record data for Saskatchewan reports. Michael Meyer (Christopher Newport University, Newport News Virginia, USA) provided critical review. Matthew Smart (University of Minnesota, St. Paul, Minnesota, USA) and George Mattox (Universidade de São Paulo, Brazil) provided guidance for improvement of several aspects of the manuscript. This paper represents AG's partial fulfillment of the service project requirement for Principles of Ecology \& Evolution (BIOL K-341) at IUPUC.

\section{Literature Cited}

Banks, N. 1918. New neuropteroid insects. Bulletin of the Museum of Comparative Zoology 62(1): 3-22.

Burks, B.D. 1953. The mayflies, or Ephemeroptera, of Illinois. Bulletin of the Illinois Natural History Survey 26(1): 1-216.

Cather, M.R. and G.L. Harp. 1975. The aquatic macroinvertebrate fauna of an Ozark and a deltaic stream. Arkansas Academy of Science Proceedings 29(1): 30-35.
Clemens, W.A. 1915. Rearing experiments and ecology of Georgian Bay Ephemeridae. Contributions of Canadian Biology, Sessional Papers, 39b: 113-128.

Clifford, H.F. and H. Boerger. 1974. Fecundity of mayflies (Ephemeroptera), with special reference to mayflies of a brown-water stream of Alberta, Canada. Canadian Entomologist 106(10): 1111-1119.

Durfee, R.S. and B.C. Kondratieff. 1994. New additions to the inventory of Colorado mayflies (Ephemeroptera). Entomological News 105(4): 222-227.

Eaton, A.E. 1883-1888. A revisional monograph of recent Ephemeridae or mayflies. Transactions of the Linnean Society of London, Second Series, Zoology 3: 1-352, 65 pl.

Faulkner, G.M. and D.C. Tarter. 1977. Mayflies, or Ephemeroptera, of West Virginia with emphasis on the nymphal stage. Entomological News 88(7\&8): 202-206.

Gyselman, E.C. 1980. The mechanisms that maintain population stability of selected species of Ephemeroptera in a temperate stream; p. 309-319 In J.F. Flannagan and K.E. Marshall (eds.). Advances in Ephemeroptera Biology. New York: Plenum Press.

Harris, S.C., B.C. Kondratieff and B.P. Stark. 1996. New records of Ephemeroptera, Plecoptera and Trichoptera from Alabama. Entomological News 107(4): 237-242.

Ide, F.P. 1930. Contribution to the biology of Ontario mayflies with descriptions of new species. Canadian Entomologist 62(9): 204-213, 62(10): 218-231.

Jacobus, L.M. and W.P. McCafferty. 2001a. Additions to the Canadian Ephemeroptera. Journal of the New York Entomological Society 109(3\&4): 367-371.

Jacobus, L.M. and W.P. McCafferty. 2001b. The mayfly fauna of New York State (Insecta: Ephemeroptera). Journal of the New York Entomological Society 109(1): 47-80.

Klubertanz, T.H. 1995. Survey of Iowa mayflies (Ephemeroptera). Journal of the Kansas Entomological Society 68(1): 20-26.

Knight, D. H. 1996. Mountains and plains. The ecology of Wyoming landscapes. New Haven, Connecticut: Yale University Press. 338 p.

Kondratieff, B.C. and R.W. Baumann. 1988. Taeniopteryx of Western North America (Plecoptera: Taeniopterygidae). Pan-Pacific Entomologist 64(4): 381-390.

Lager, T.M., M.D. Johnson and W.P. McCafferty. 1982. The mayflies of northeastern Minnesota (Ephemeroptera). Proceedings of the Entomological Society of Washington 84(4): 729-741.

Lehmkuhl, D.M. 1976. Mayflies. Blue Jay (Saskatchewan Natural History Society) 34(2): 70-81.

Mathers, J.S. 1978. The Effects of Highway Construction on Galt Creek, Ontario. Peterborough, Ontario: Ontario Ministry of Natural Resources. 115 p.

McCafferty, W.P. 2000. Reporting species record data. Entomological News 111(4): 311-312.

McCafferty, W.P. 2009. New state and provincial North American records for 100 Ephemeroptera species. Transactions of the American Entomological Society 135(3\&4): 353-368.

McCafferty, W.P. and R.P. Randolph. 1998. Canada mayflies: a faunistic compendium. Proceedings of the Entomological Society of Ontario 129: 47-97.

McCafferty, W.P., R.P. Randolph and L.M. Jacobus. 2012. Mayflies of the Intermountain West. Memoirs of the American Entomological Institute 85: 1-317.

McCafferty, W.P., T. Hubbard, T.H. Klubertanz, R.P. Randolph and M. Birmingham. 2003. Mayflies (Ephemeroptera) of the Great Plains. II: Iowa. Transactions of the American Entomological Society 129(1): 77-105.

McCafferty, W.P., D.R. Lenat, L.M. Jacobus and M.D. Meyer. 2010. The mayflies (Ephemeroptera) of the southeastern United States. Transactions of the American Entomological Society 136(3\&4): 221233.

McDunnough, J. 1925a. Ephemeroptera; p. 104-106 In N. Criddle (ed.). The Entomological Record, 1924. Annual Report of the Entomological Society of Ontario 55: 89-106.

McDunnough, J. 1925b. New Canadian Ephemeridae with notes. III. Canadian Entomologist 57(7): 168-176, 57(8): 185-192.

McDunnough, J. 1925c. The Ephemeroptera of Covey Hill, Que. Transactions of the Royal Society of Canada, Third Series 19(5): 207224, 1 pl.

Melin, R.E. 1964. Description and origin of uranium deposits in Shirley Basin, Wyoming. Economic Geology 59(5): 835-849.

Needham, J.G. 1905. Ephemeridae; p. 17-62 In J.G. Needham, K.J. Morton and O.A. Johannsen. May Flies and Midges of New York. New York State Museum Bulletin 86 (Entomology 23): 1-352.

Randolph, R.P. and W.P. McCafferty. 1998. Diversity and distribution of the mayflies (Ephemeroptera) of Illinois, Indiana, Kentucky, Michigan, Ohio, and Wisconsin. Ohio Biological Survey Bulletin (New Series) 13(1): 1-188. 
Ruiter, D. E. 1990. A new species of Neotrichia (Trichoptera: Hydroptilidae) from Colorado with additions and corrections to the distributions and records of Colorado Trichoptera. Entomological News 101(2): 88-92.

Ruiter, D.E. and R.J. Lavigne. 1985. Distribution of Wyoming Trichoptera. University of Wyoming Agricultural Experiment Station Publication SM47: 1-102.

Sarver, R. and B.C. Kondratieff. 1997. Survey of Missouri mayflies with the first description of adults of Stenonema bednariki (Ephemeroptera: Heptageniidae). Journal of the Kansas Entomological Society 70(2): 132-140.

Spieth, H.T. 1941. The North American Ephemeropteran types of the Rev. A. E. Eaton. Annals of the Entomological Society of America 34(1): 8798

Traver, J.R. 1935. Part II: Systematic; p. 237-739 In J.G. Needham, J.R Traver and Y.-C. Hsu. The Biology of Mayflies, with a Systematic Account of North American Species. Ithaca, New York: Comstock. 759 p.

Walker, F. 1852. Catalogue of the Specimens of Neuropterous Insects in the Collections of the British Museum. Part 1. London: Trustees of the British Museum. $192 \mathrm{p}$.
Webb, J.M., L.M. Jacobus, D.H. Funk, X. Zhou, B. Kondratieff, C.J. Geraci, R.E. DeWalt, D.J. Baird, B. Richard, I. Phillips and P.D.N. Hebert. 2012. A DNA barcode library for North American Ephemeroptera: progress and prospects. PLOS ONE 7(5): e38063.

Zhou, X., S.J. Adamowicz, L.M. Jacobus, R.E. DeWalt and P.D.N. Hebert. 2009. Towards a comprehensive barcode library for Arctic life: Ephemeroptera, Plecoptera and Trichoptera of Churchill, Manitoba, Canada. Frontiers in Zoology 6(30): 1-9.

Zhou, X., L.M. Jacobus, R.E. DeWalt, S.J. Adamowicz and P.D.N. Hebert. 2010. The Ephemeroptera, Plecoptera, and Trichoptera fauna of Churchill (Manitoba, Canada): insights into biodiversity patterns from DNA barcoding. Journal of the North American Benthological Society 29(3): 814-837.

RECEIVED: July 2012

ACCEPTED: July 2012

Published online: August 2012

EDITORIAL RESPONSIBILITY: Matthew Smart 